\title{
O.S.P.
}

L'orientation scolaire et professionnelle

$47 / 4$ | 2018

Varia

\section{8/2 - Proposition d'une méthode de restitution de tests}

Sylvie Lyons Poiraud

\section{(2) OpenEdition}

\section{Journals}

Édition électronique

URL : http://journals.openedition.org/osp/9728

DOI : $10.4000 /$ osp.9728

ISSN : 2104-3795

Éditeur

Institut national d'étude du travail et d'orientation professionnelle (INETOP)

\section{Édition imprimée}

Date de publication : 1 décembre 2018

Pagination : 733

ISSN : 0249-6739

\section{Référence électronique}

Sylvie Lyons Poiraud, «38/2 - Proposition d'une méthode de restitution de tests », L'orientation scolaire et professionnelle [En ligne], 47/4 | 2018, mis en ligne le 01 décembre 2020, consulté le 18 décembre 2020. URL : http://journals.openedition.org/osp/9728 ; DOI : https://doi.org/10.4000/osp.9728

Ce document a été généré automatiquement le 18 décembre 2020.

(c) Tous droits réservés 


\title{
38/2 - Proposition d'une méthode de restitution de tests
}

\author{
Sylvie Lyons Poiraud
}

\section{RÉSUMÉS}

Dans un contexte où les outils d'évaluation deviennent de plus en plus pointus, il semble pertinent de réfléchir à leur mode de restitution. Cet article présente une méthode basée sur les apports du dialogisme, une école de pensée qui réfléchit au sens profond du dialogue. La démarche s'appuie sur une conception du sujet actif dans son développement en accordant de l'importance à son autoperception. Elle met l'accent sur la nécessité de respecter deux temps distincts : celui de la passation, qui est consacré au partage des savoirs (empowerment); celui de l'interprétation conjointe, qui permet de co-construire autour du sens des scores.

\section{INDEX}

Mots-clés : alliance de travail, co-construction du sens, dialogisme, interprétation conjointe, réflexivité, restitution de test 